\title{
Is science a job for governments?
}

\author{
The British government's call for advice on science policy raises the question of what government's role \\ should be.
}

THE British government is not alone in seeking to enhance prosperity by the more effective application of science, research in particular. President Bill Clinton has spoken more often of "technology transfer" than of research. Among European governments, the French has been the most successful; since President François Mitterrand's election in 1980, strong links have been forged between research institutes and industrial companies while revitalizing much of academic research - but at considerable cost in annual budgets. The experience of Japan, on the other hand, impressive and even startling though it is, is less relevant. Even in recent decades, Japan's technology has rested not on a transfer but a recruitment policy. Bright young people have been recruited into lifelong careers of training and hard work by companies persuaded that only technology could allow them to succeed. Only now has it become apparent that the policy is too shallow for the long run, and that the government must invest in basic science.

The British determination to reorganize the part of the scientific enterprise the government controls directly is nevertheless warmly to be welcomed. Taxpayers will rejoice if the edge can be taken off seemingly chronic economic difficulties. The scientific community would also like to be rid of the common suspicion that it consists of a bunch of layabouts, unaccountable spenders of public funds. But there are dangers. The article on page 581, which is meant to provide background reading for those attending public meetings in Edinburgh this week and London next month, draws attention to some of the risks. Nobody denies that the impending reorganization is important. It could bring huge benefits but, if misconceived, it could do great damage. Is it not always thus with important matters of public policy?

The chief danger is that the two partners in any scientific enterprise - basic research and its application - will be dealt with as if they are at opposite poles of a wide spectrum. The ground for that suspicion is the frequently expressed opinion of British industrialists, openly reflected in some of the advice the government has been given, that basic research, being untied to immediate goals, is irrelevant to wealth-creation. That calculation overlooks not just the importance of basic science as a source of innovation of technique (which can in principle be picked up from books and journals) but the role of basic research in the training of able young men and women.

That is why this journal has consistently held that one ingredient of a new policy for British research should be to make the training of people the centrepiece of the justification of basic research. There are awkward implications, of course. Graduate students' stipends would have to be increased. (Why should the people to whom Britain trusts its future be paid less than a half of the average wage?) Graduate students would have to qualify for their right to embark on a research degree, but then would have more freedom than at present to influence their own course of studies. It would also make sense that public support for basic science should be partly redirected towards those fields of research in which the gap between discovery and application is smallest, not so much for the innovations that would flow but for the increased supply of skill that there would be. (In molecular biology now, the gap seems to have vanished altogether.)

But it would be folly to suppose that reforms of this kind, long overdue, would be enough to win the British government the prize it seeks. It is all too well known that most British companies have yet to be persuaded of the truths their Japanese peers live by in what is now the global economy - that the products that command attention are those developed with daring and almost endless trouble. Britain, by contrast, has a long history of halfbaked development, from the Comet aircraft of the 1950s to the airborne radar system abandoned three years ago in favour if the superior US AWACS - both of these in fields in which the British government has lavished substantial funds. One of the government's problems for the weeks ahead is to find ways of making British companies pay attention to the importance of research and development.

A greater difficulty lies closer to the government's own doorstep. Inevitably, the administration of government policy falls on the shoulder of officials. And while the British civil service is proud of its incorruptible intelligence, it is far from being technically literate. Too often, the people whose duty is to advise on the fate of great projects do not properly understand what they are about. That fault, coupled with the habit of secretiveness that still pervades the British habit of government, means that many decisions are ill-judged. For the same reasons, the government is less than able to take the initiative on technical matters. By good fortune the minister in charge of science also has responsibility for the British civil service. Something must be done about it.

But is it not the proper role of government to create the climate in which science and technology can prosper, and then to stand aside? That is the present government's belief. But in science as in other fields (monetary policy, for example) the past ten years have not created the conditions under which the government can let problems solve themselves. Cajoling industry into taking research and development seriously will require that money should be spent, preferably on projects rather than tax-breaks. Outside industries such as pharmaceuticals, British industry also needs some illustrations to demonstrate that it can succeed in radical innovations. Talk from on high can help, but it must be perceptive talk, not empty exhortation. 